\title{
STARLINGS BANDED ON WINTERING GROUNDS AND RECOVERED IN SASKATCHEWAN
}

\author{
C. STUART HOUSTON, 863 University Drive, Saskatoon, SK S7N 0J8. E-mail: \\ stuart.houston@usask.ca
}

European Starlings were released in Central Park, New York City in 1890 by Eugene Schieffelin as part of an effort to introduce into the United States all the birds mentioned in Shakespeare's sonnets and plays. By 1950, starlings had expanded across the Canadian prairies and British Columbia, and to all but the coastal rim of the Pacific states. "Migratory behavior appeared soon after introduction." 2

In 1960, Johnson A. Neff began banding starlings at Monmouth, Oregon and Caldwell, Idaho, when "starling depredations and nuisance problems have begun to pyramid in the West, especially in Oregon, Washington and Idaho." He mapped starling recoveries in the first year of banding and these included six recoveries of Idaho birds in western Saskatchewan. ${ }^{5}$ Neff's work was the forerunner of a more comprehensive, ten-year program of starling banding in fruit-growing states, particularly Oregon and California.

Although starling movements from the Great Lakes and Midwest regions of the United States have been analyzed by Dolbeer, ${ }^{3}$ starling movements into and out of Saskatchewan were unknown. A single vector plot that synopsized movements of the 22,467 starlings banded in the Pacific flyway through 1973 indicated that the major direction taken by starlings banded in California was only slightly east of north, to the interior of British Columbia, with no indication that any came as far as Saskatchewan. ${ }^{1}$

Although I have banded 73 nestling Starlings in 15 different years between 1966 and 2005, I have yet to receive a recovery or encounter, in spite of starling control programs that kill many individual birds in some fruit orchards in the western United States.

If one cannot learn starling routes from birds banded in Saskatchewan, why not map information from birds banded on the wintering grounds and recovered in Saskatchewan? The map in Figure 1 is based on printouts of all 52 Saskatchewan recoveries from banding in the United States and British Columbia between 1938 and 1977. All but two of these starlings had been banded in the United States between 1960 and 1970, the exceptions being one banded in North Dakota in 1938 and the last of the recovered birds, banded in British Columbia in 1977.

The following list gives the location of banding in italics and, in parentheses, the number of birds recovered in Saskatchewan, followed by the exact location where they were found. An asterisk indicates that the tenminute block of latitude and longitude referred to is the one immediately adjacent-south (S), north (N), east (E) or west $(W)$-of the location listed. White 
Bear $S^{*}$, for example, refers to the tenminute block of latitude and longitude south of the block occupied by White Bear village.

British Columbia (1, at Pierceland).

California (15, at Kenaston, White Bear $\mathrm{S}^{*}$, Bruno, Fairy Glen, Hague $E^{*}$, Lajord, Cavell, Alsask twice, Simmie, Beatty, Duck Lake $W^{*}$, Glidden, Avonlea, Revenue).

Colorado $(3$, at Welwyn, Belle Plaine $W^{*}$, Griffin).

Idaho (8, at Biggar $\mathrm{N}^{*}$, Simmie, Luseland, Smiley, Druid, Tugaske, Mantario, and Eatonia).
Nevada (4, at Crichton, Rabbit Lake $\mathrm{N}^{*}$, Bethune, Pilger).

North Dakota (3, at Tyvan, Heward N*, and Northgate).

Oregon (15, at Waseca, Lashburn, Saskatoon, Unity $W^{*}$, Neidpath, Horsham, Birsay, Beechy, Cactus Lake $W^{*}$, Shellbrook, Hatton $W^{*}$, Shamrock, Lake Lenore, Goodsoil $\mathrm{S}^{*}$, and Biggar).

Utah $\left(1\right.$, at Chaplin $\left.W^{*}\right)$.

Washington (2, at Plenty and Northminster).

Of the 52 birds recovered in Saskatchewan, three were released alive and the rest were dead when found or died soon after: 15 were found dead; 14 shot; 3 were injured and died; 3 drowned; 3 killed by cat; 3 caught in trap and died; 2 caught in building, of which one was released; 2 caught by hand and released; and 1 each killed by weather, disease, electrocution, an unspecified bird predator, and by striking an object. Two were "band only." The oldest was five years.

\section{Acknowledgments}

I thank Louise Laurin in the Canadian bird banding office in Ottawa for the electronic printout of S a skatchewan

Figure 1. Starlings banded elsewhere and recovered in Saskatchewan Map by Kathy M. Meeres 
recoveries and Kathy $M$. Meeres for the map.

1. BURTT, H.E., and M.L. GILTZ. Seasonal directional patterns of movements and migrations of starlings and blackbirds in North America. BirdBanding 48:259-271.

2. CABE, P.R. 1993. European Starling (Sturnus vulgaris). In The Birds of North America, No. 48 (A. Poole and F. Gill, Eds.). Philadelphia: The Academy of Natural Sciences; Washington, D.C.: The American Ornithologists' Union.

3. DOLBEER, R.A. Migration patterns for age and sex classes of blackbirds and starlings. Journal of Field Ornithology 53:28-46.

4. NEFF, J.A. 1961. On banding starlings. News from the Bird-Bander 36:9-10-11. [News from the
Bird-Bander was renamed Western Bird Bander in 1962].

5. NEFF, J.A. 1962. Starling recovery map. Western Bird Bander 37:121.

Editor's Note: We believe that Eugene Schieffelin's name is spelled correctly in this article, as it agrees with the spelling of Schieffelin Avenue in New York City, which was named after him. Other spellings of this man's name that appear in published works and on the Internet are Scheifflin, Scheifflen and Scheiffelin. We would appreciate hearing from anyone who has additional information about this.

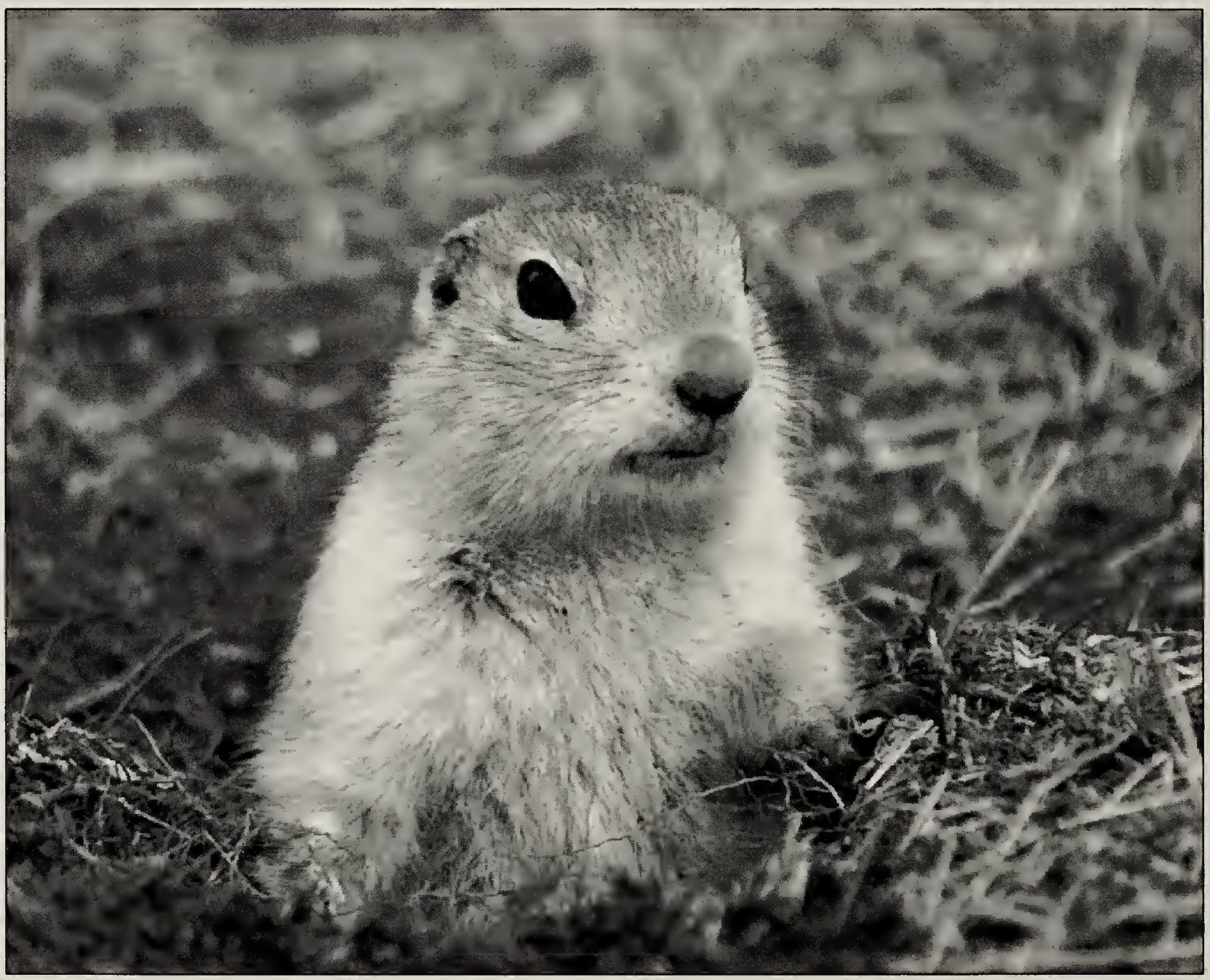

Ground Squirrel

Randy McCulloch 